\title{
Kualitas Jajanan Siswa di Sekolah Dasar
}

\author{
Riris Lindiawati Puspitasari \\ Program Studi Biologi, Fakultas Sains dan Teknologi, \\ Universitas Al Azhar Indonesia, Jl. Sisingamangaraja, Jakarta 12110 \\ E-mail: riris.lindiawati@uai.ac.id
}

Abstrak - Kebersihan makanan dan minuman sangatlah penting, karena berkaitan dengan kondisi tubuh manusia, terutama makanan dan minuman yang dikonsumsi oleh anak-anak, karena mereka memiliki imunitas yang lebih rentan terhadap penyakit. Namun, kebanyakan dari anak usia sekolah mempunyai kebiasaan untuk jajan. Sering kali jajanan tersebut dijajakan di pinggir jalan atau di pinggir saluran pembuangan air dan ditempatkan pada area terbuka sehingga memudahkan terjadinya kontak antara pangan yang dijajakan dengan mikroba. Padahal mikroba adalah salah satu penyebab dari berbagai penyakit (foodborne disease). Penelitian ini meneliti kualitas makanan jajanan anak sekolah dasar dengan melihat adanya bakteri Escherichia coli yang terkandung dalam jajanan tersebut. Sampel makanan berasal dari penjaja jajanan yang berdagang di sekitar sekolah dasar di daerah Sisingamangaraja. Sampel yang diambil merupakan makanan yang tidak mengalami pemanasan sebelum disajikan dan minuman yang dibuat saat akan disajikan dan tidak dikemas secara tertutup. Dilakukan tiga metode pengujian, yaitu uji pemeriksaan mikroba, uji pemeriksaan Coliform dan uji konfirmasi E.coli. uji pemeriksaan mikroba menggunakan Nutrient Agar sebagai media umum, uji pemeriksaan Coliform menggunakan Lactose Broth dan Brilliant Green Lactose Broth sebagai media khusus untuk menguji keberadaan Coliform, dan uji konfirmasi Eschrichia coli menggunakan Eosin Methylane Blue Agar sebagai media khusus untuk pengujian Escherichia coli. Data yang diperoleh menunjukkan hasil yang positif terhadap adanya bakteri pada media umum, bakteri Coliform dan diduga terdapat bakteri Escherichia coli pada kedua sampel. Untuk itu, diperlukan pengujian lebih lanjut guna memastikan bakteri yang terkandung adalah Escherichia coli.
Abstract - Food and beverage hygiene are important because they will influence human health condition, especially for children. As we know children have immunity that more susceptible to diseases. In deed, school-aged children like eating snacks after school time. These snacks were sold at the roadside or near to drain water and placed in an open area which made an open access for food being contaminated by microbes. Some pathogen microbes could infect human by causing foodborne disease. The aim of study was to examine the quality of street food that sold near to the elementary school. The experiment was conducted by analyzing Escherichia coli in their snack food. Samples were taken from public elementary school located in Sisingamangaraja. The inclusion criterias for samples either food or drinks were no prewarmed and completely packaged. Bacteria growth media used in this study were Nutrient Agar, Lactose Broth, Brilliant Green Lactose Broth. By using these media, bacteria colonies could grow after incubation for several hours. Escherichia coli growth was visible in Eosin-Methylane Blue Agar media. Escherichia coli observed positively in Eosin-Methylane Blue Agar media from two snack samples. In order to confirm $E$. coli growth in the samples, we need to conduct another tests which would reveal more specific and selective data.

Keywords - Quality of Street Food, Coliform, Escherichia coli, Food and Beverage Hygiene, Elementary School.

\section{PENDAHULUAN}

Kebersihan makanan dan minuman sangatlah Kenting karena berkaitan dengan kondisi tubuh manusia. Apabila makanan dan minuman yang dikonsumsi tidak terjaga kebersihannya maka 
dapat menimbulkan berbagai macam penyakit, mulai dari penyakit ringan yang tidak membahayakan sampai penyakit berat, membahayakan jiwa. Oleh karena itu, kebersihan makanan dan minuman sangatlah penting untuk dijaga, terutama makanan dan minuman dikonsumsi oleh anak-anak, karena mereka memiliki imunitas yang lebih rentan terhadap penyakit. Namun, kebanyakan dari anak usia sekolah mempunyai kebiasaan untuk jajan sehabis waktu sekolah selesai. Sering kali jajanan tersebut dijajakan di pinggir jalan atau di pinggir saluran pembuangan air dan ditempatkan pada area terbuka sehingga, memudahkan terjadinya kontak antara pangan yang dijajakan dengan mikroba. Padahal mikroba adalah salah satu penyebab penyakit diare. Anak usia sekolah mudah terserang penyakit diare, karena jajanan yang mereka konsumsi mudah tercemar oleh mikroba. Karena itu penting untuk mengetahui jumlah cemaran mikroba pada jajanan anak, khususnya penyebab diare. Bakteri penyebab diare antara lain adalah Escherichia coli (E.coli).

E.coli adalah bakteri yang sering dijadikan standar utama kebersihan pangan, karena bakteri ini merupakan indikasi awal adanya cemaran-cemaran bakteri lain yang dapat menyebabkan penyakit diare ini. E.coli tidak hanya dapat mencemari makanan jajanan, tetapi juga mencemari sumber air, sehingga air yang tercemar tidak layak untuk dikonsumsi Air yang tercemar oleh E.coli tidak boleh dikonsumsi atau digunakan untuk keperluan yang berhubungan dengan makanan dan minuman. Apabila air tersebut digunakan, maka makanan atau minuman dapat ikut tercemar, sehingga dapat membahayakan anak sekolah yang mengkonsumsi makanan atau minuman tersebut. Penyakit seperti diare atau keracunan makanan dapat terjadi.

Topik ini dipilih dikarenakan pentingnya kebersihan dari makanan dan minuman, khususnya jajanan yang dikonsumsi oleh anak usia sekolah. Anak usia sekolah rentan terhadap penyakit sehingga perlu diketahui bersih atau tidak jajanan yang mereka konsumsi dengan melihat jumlah cemaran E.coli. Berdasarkan observasi awal di lokasi, terdapat kecenderungan tingginya minat siswa untuk membeli jajanan di sekitar sekolah terutama di pagi hari dan jam istirahat tanpa memperhatikan kebersihan dan keamanan jajanan. Selain itu, berdasarkan sosialisasi awal tentang kebersihan jajanan di salah satu kelas didapatkan fakta bahwa hampir 30\% siswa pernah menderita penyakit diare dan tifus. Berdasarkan hal tersebut maka penulis terdorong untuk melakukan pengkajian lebih mendalam mengenai kebersihan dan keamanan jajanan di sekitar sekolah. Hasil dari penelitian ini diharapkan dapat memberi informasi terhadap masyarakat terutama untuk para orang tua tentang kebersihan dan keamanan jajanan yang dikonsumsi oleh anak di sekitar lokasi sekolah.

\section{TINJAUAN PUSTAKA}

FAO mendefinisikan makanan jajanan sebagai makanan dan minuman yang disajikan dalam wadah atau sarana penjualan di pinggir jalan, tempat umum atau tempat lainnya, yang terlebih dahulu sudah dipersiapkan atau dimasak di tempat produksi, di rumah atau di tempat berjualan. Makanan jajanan dapat berupa minuman atau makanan dengan jenis, rasa, dan warna yang bervariasi dan memikat. Variasi rasa, jenis dan terutama warna yang memikat dan menarik minat anak sekolah untuk membeli makanan jajanan. Sekarang ini, jajan menjadi sebagai kebiasaan anak sepulang sekolah. Dikutip dari buletin InfoPOM, kebiasaan orang tua memberikan uang jajan dan tidak menjadikan bekal adalah salah satu alasan terbentuknya kebiasaan jajan pada anak sekolah [1].

Makanan jajanan dapat ditemukan hampir di setiap sekolah dasar biasanya, terdapat di luar sekolah atau dalam sekolah. Makanan jajanan ditempatkan di tempat yang terbuka dan terkadang dicampur bahan-bahan yang berbahaya. Hal ini menyebabkan makanan jajanan menjadi tidak sehat dan berbahaya untuk dikonsumsi, hasil penelitian yang dilakukan Badan Pengawas Obat dan Makanan Republik Indonesia (BPOM RI) dan Institut Pertanian Bogor (IPB) membuktikan 35\% jajanan anak sekolah di Indonesia tidak sehat dikonsumsi [2].

Anak sekolah dasar memiliki imunitas yang lebih rentan dibandingkan orang dewasa. Konsumsi makanan jajanan yang mengandung cemaran biologis ataupun kimiawi sangat berbahaya bagi kesehatan dan keselamatan anak [3]. Makanan yang tercemar cemaran biologis dapat mengandung bakteri, virus, cacing, dan lain-lainnya berbahaya bagi kesehatan. Apabila bahan makanan atau minuman makanan jajanan tercemar telur cacing perut maka, dapat menyebabkan anemia atau kekurangan darah pada anak [4]. Kasus mewabahnya penyakit hepatitis A adalah contoh kurang bersihnya makanan jajanan anak sekolah, sehingga makanan tercemar oleh virus hepatitis. Salmonella sp, Escherichia coli, dan lain-lain 
adalah contoh bakteri yang dapat mencemari makanan jajanan. Infeksi dari kedua bakteri ini dapat menyebabkan diare akut yang dapat membahayakan jiwa anak [5]. Selain itu, salah satu varian E. coli O157:H7 mampu menyebabkan hemoragik akut akibat proses pematangan makanan cepat saji yang tidak sempurna dan proses pembekuan daging yang tidak optimal [6].

\section{METODE}

Penelitian dilaksanakan di Laboratorium Mikrobiologi Fakultas Sains dan Teknologi Universitas Al Azhar Indonesia. Waktu penelitian dimulai dari bulan Maret sampai Oktober.

Sampel jajanan makanan dan minuman yang digunakan didapat dari penjaja makanan yang berjualan di sekitar sekolah dasar di daerah Sisingamangaraja. Kriteria dalam pemilihan sampel makanan adalah makanan yang tidak melalui pemanasan ulang saat akan disajikan. Sedangkan kriteria pemilihan sampel minuman adalah minuman yang dibuat saat akan disajikan dan tidak dikemas secara tertutup.

Dalam penelitian ini dilakukan tiga metode pengujian, yaitu uji pemeriksaan mikroba, uji pemeriksaan Coliform dan uji konfirmasi E.coli. Preparasi sampel menggunakan media cair Peptone. Pada pemeriksaan mikroba menggunakan media Nutrient Agar. Pengamatan hasil dari metode ini dilihat dari ada tidaknya koloni bakteri yang terbentuk. Hasil dapat diamati secara visual. Pemeriksaan coliform menggunakan dua buah media cair, yaitu Lactose Broth (LB) dan Briliant Green Lactose Bile (BGLB) Broth 2\%, hasil dapat diamati dari adanya pembentukkan gas pada media. Pemeriksaan adanya mikroba dan Coliform bertujuan untuk melihat kemungkinan terdapat E.coli pada sampel. Sedangkan, uji konfirmasi E.coli bertujuan untuk memastikan bahwa E.coli terdapat pada sampel. Uji ini menggunakan media Eosin Methyilane Blue Agar (EMB). Media ini merupakan media selektif yang memperlihatkan ciri-ciri tertentu apabila terdapat E.coli pada sampel. Alur kerja seperti yang terlihat pada Gambar $1[7,8,9]$.
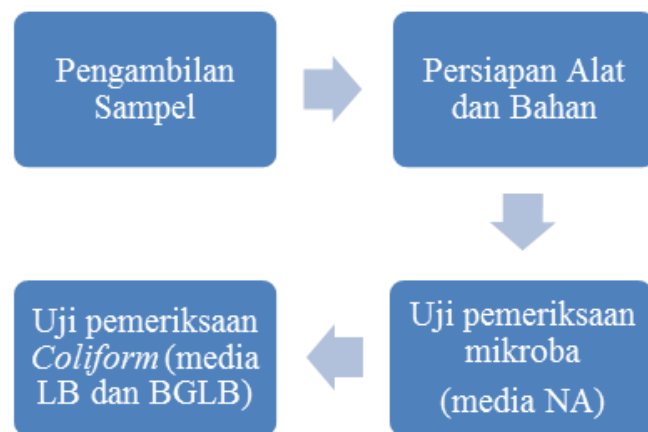

Uji pemeriksaan mikroba

(media NA)

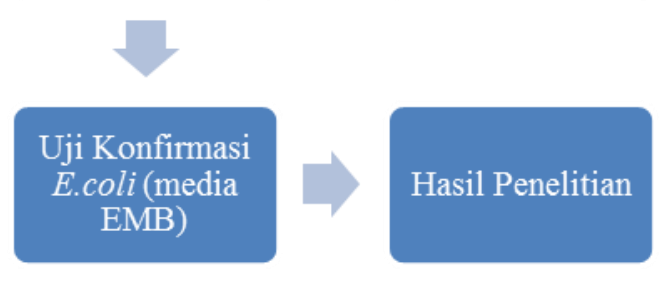

Gambar 1. Alur Kerja

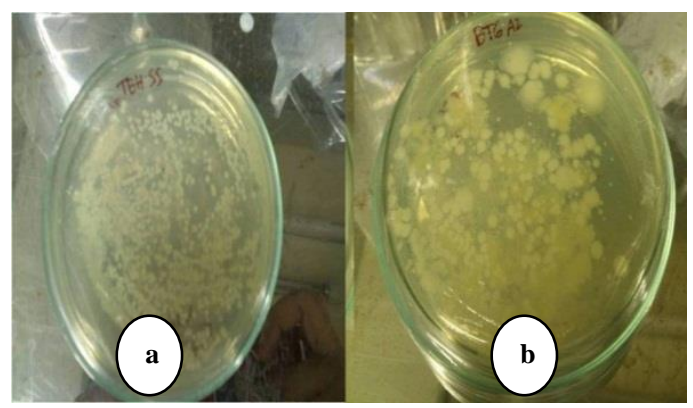

Gambar 2. Sampel hasil uji adanya mikroba dalam media NA (a) sampel minuman (b) sampel makanan

Kultur bakteri E.coli yang digunakan diperoleh dari Laboratorium Mikrobiologi Klinik Fakultas Kedokteran Universitas Indonesia.

\section{HASIL DAN PEMBAHASAN}

Pada penelitian ini, dilakukan beberapa macam pengujian untuk melihat kebersihan suatu makanan jajanan, dilihat dari kandungan mikrobiologisnya. Pengujian pertama merupakan inokulasi sampel ke dalam media NA untuk melihat keberadaan bakteri pada sampel. Hasil pengujian ini adalah ditemukan adanya bakteri pada kedua sampel.

Pada Gambar 2 terlihat adanya koloni bakteri yang tumbuh hampir menutupi permukaan cawan petri. Hasil dari pengujian ini mampu memberikan informasi mengenai keberadaan mikroba pada sampel dikarenakan media NA merupakan media umum dan tidak bersifat selektif. 
Pengujian kedua melakukan pemeriksaan adanya bakteri Coliform pada sampel. Pembuktian adanya bakteri jenis Coliform bertujuan sebagai data pendukung dalam menentukan adanya E.coli, karena Coliform merupakan kelas bakteri-bakteri penghuni usus manusia atau hewan berdarah panas dan E.coli termasuk didalamnya sehingga pengujian Coliform dapat menjadi data awal mengenai ada atau tidaknya E.coli.

Pemeriksaan adanya bakteri Coliform menggunakan media LB dan BGLB. Kedua sampel memberikan hasil yang positif terhadap keberadaan Coliform, seperti yang terlihat dalam Gambar 3 dan Gambar 4.

Pengujian ini memerlukan ketelitian untuk memasukkan tabung Durham ke dalam tabung reaksi berisi media LB atau BGLB. Gas dapat masuk ke dalam tabung Durham sehingga pengamatan tidak dapat dilanjutkan. Setelah diketahui adanya keberadaan Coliform pada

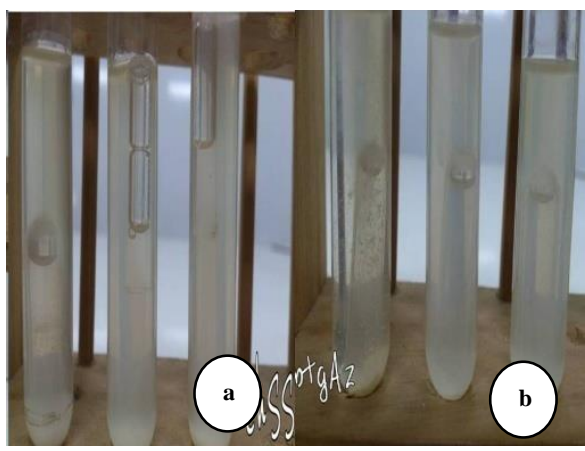

Gambar 3. Sampel hasil uji adanya mikroba dalam media LB (a) sampel minuman (b) sampel makanan.

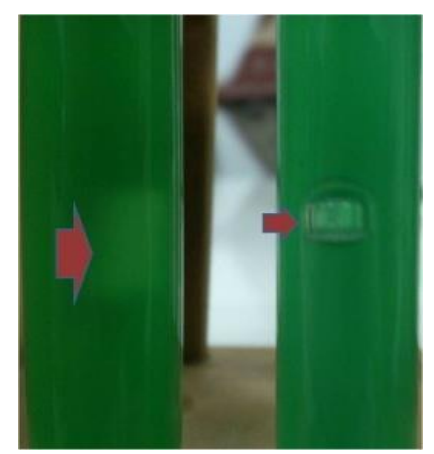

Gambar 4. Sampel minuman hasil uji adanya mikroba dalam media BGLB. Tanda panah menunjukkan adanya gelembung gas dalam tabung Durham sampel, dilakukan pengujian ketiga menggunakan media EMB untuk mengetahui adanya E.coli.

Media EMB digunakan karena bersifat selektif dan deferensial. Dalam media ini, bakteri E.coli memiliki warna kehijauan sehingga mudah untuk diamati. Berdasarkan observasi didapatkan adanya pertumbuhan E.coli pada kedua sampel (Gambar $5)$.

Adanya E.coli dapat menjadi indikator tercemarnya makanan jajanan terhadap feces manusia ataupun hewan berdarah panas lainnya. Tidak semua strain E.coli dapat menyebabkan terjadinya penyakit. Namun, keberadaan E.coli pada makanan atau minuman dapat menjadi indikator adanya bakteri patogen lain, seperti Salmonella dan Shigella.

Terdeteksi adanya cemaran Coliform pada jajanan dapat dikarenakan kurangnya perhatian penjaja pada kebersihan. Berdasarkan pengamatan, para penjaja menjajakan makanan atau minumannya di areal luar sekolah. Areal luar sekolah merupakan jalan umum yang sering di lewati oleh kendaraan bermotor. Sampel batagor yang dijajakan tidak diletakkan dalam wadah khusus secara tertutup. Setelah digoreng, sampel batagor didiamkan di tempat terbuka untuk dijual.

Penempatan batagor pada areal terbuka memudahkan sampel kontak dengan mikroba. Selain itu, tidak adanya pemanasan ulang menyebabkan bertambahnnya kandungan mikroba pada sampel.

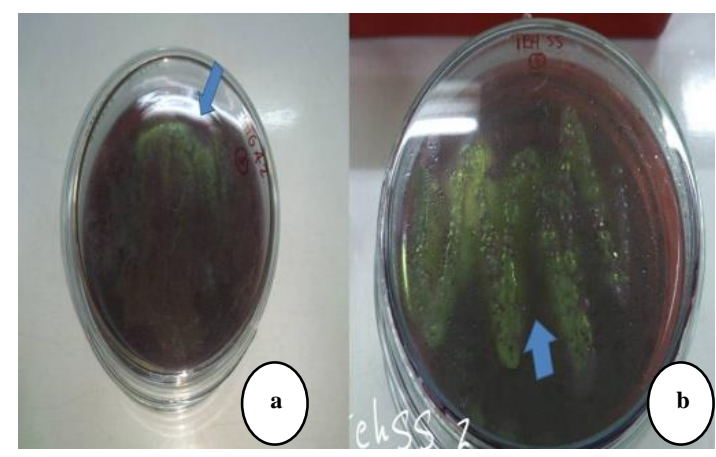

Gambar 5. Sampel hasil uji adanya mikroba dalam media EMB (a) sampel makanan (b) sampel minuman. Tanda panah menunjukkan perubahan warna media akibat pertumbuhan $E$. coli 
Sumber kontaminasi utama pada sampel minuman dapat berasal dari air dan es yang digunakan. Air yang tidak mengalami proses pemasakan menyebabkan tumbuhnya mikroba pada air sehingga minuman jajanan juga ikut tercemar. Selain itu, kurangnya perhatian penjaja terhadap kebersihan diri dapat menjadi sumber kontaminasi pada jajanan yang dijajakan.

Rantai penyebaran foodborne disease tidak hanya dilakukan dengan memutus satu mata rantai tapi membutuhkan penanganan berkelanjutan agar kasus terjadinya wabah di suatu lokasi tidak terjadi [10]. Terjadinya wabah foodborne disease juga berpotensi menyebabkan kerugian dari segi biaya. Analisis biaya penatalaksanaan akibat infeksi E.coli membutuhkan penanganan dan perhatian khusus, seperti halnya pada infeksi akibat Clostridium perfringens, E. coli non-O157, Shigella, Yersinia, dan Hepatitis A [11].

\section{KESIMPULAN}

Dari hasil penelitian ini didapatkan informasi mengenai adanya cemaran bakteri Escherichia coli pada keenam sampel makanan dan minuman yang di ambil di sekolah dasar. Selain itu, pada keenam sampel terdapat cemaran bakteri Coliform dan bakteri yang tumbuh pada media NA sebagai media umum.

Kelanjutan penelitian ini disarankan melakukan pengujian tambahan untuk mengkonfirmasi keberadaan Escherichia coli pada sampel. Pengujian tambahan dapat menggunakan media Escherichia coli broth, pewarnaan Gram, dan uji IMVIC.

\section{UCAPAN TERIMA KASIH}

Dana penelitian ini diperoleh dari Lembaga Penelitian dan Pengabdian Masyarakat (LP2M) Universitas Al Azhar Indonesia. Laboratorium mikrobiologi FKUI atas bantuan kultur murni Escherichia coli.

\section{DAFTAR PUSTAKA}

[1] Badan pengawas obat dan makanan Republik Indonesia (BPOM). Pengujian mikrobiologi pangan. Info POM Vol. 9, No. 2, Maret 2008.

[2] Anon., Awas jajanan anak, BPOM temukan 35\% jajanan tak sehat bagi anak sekolah, Republika.co.id, http://www.republika.co.id/berital nasional/umum/11/11/20/luygji, 2011. (Diakses pada 15 Februari 2011).

[3] Lestari Tri Puji, Skripsi, Universitas Muhammadiyah Surakarta, Surakarta, 2008.

[4] Anon., Bahaya makanan jajanan di sekitar kita,Pondokibu.com,

http://pondokibu.com/2862,2011.(Diakses pada 15 Februari 2011).

[5] Suharyono, Diare Akut Klinik Laboratorik, PT Rineka Cipta, Jakarta, 2008.

[6] R.L. Buchanan, M.P. Doyle, Foodborne disease significance of Escherichia coli O157:H7 and other enterohemorrhagic E. coli. Food Technology Vol. 51 No. 10, 1997.

[7] Widjianti, Ni Luh Putu M., dan Ristianti Ni Putu, Analisis Kualitatif Bakteri Koliform Pada depo Air Minum Isi Ulang Di Kota Sisingaraja Bali. Jurnal Ekologi Kesehatan Vol 3 No 1 : 64-73, 2004.

[8] Susanna, Dewi., dan Hartono, Budi, Pemantauan Kualitas Makanan Ketoprak Dan Gado-Gado Di Lingkungan Kampus Ui Depok, Melalui Pemeriksaan Bakteriologis, Makara, Seri Kesehatan, Vol. 7, No. 1, Juni 2003.

[9] Fardiaz, Srikandi, Analisis Mikrobiologi Pangan, Pt Raja Grafindo, Jakarta, 1993.

[10] L. Zelenakova, J. Ziarovska, D. Kozelova, Mura, Lopasovsky, Campylobacteriosis: Importance of strengthening surveillance and reported foodborne disease control within European Union. Journal of Microbiology, Biotechnology and Food Sciences, February (1):855-867, 2012.

[11] RL. Scharff, Economic burden from health losses due to foodborne illness in the united states, Journal of Food Protection Vol. 75, No. 1: 123-31, 2012. 